\title{
The Causal Relationship Between Temperature Change and Food Indices in The World
}

\author{
N. Alhas Eroglu ${ }^{1, *}$, M. Bozoglu², U. Baser², B. Kilic Topuz ${ }^{3}$ \\ ${ }^{1}$ Regional Directorate of Turkish Statistical Institute, 55080 Samsun, Turkey \\ ${ }^{2}$ Ondokuz Mayis University, Faculty of Agriculture, Department of Agricultural Economics, 55139 Samsun, Turkey \\ ${ }^{3}$ Igdir University, Faculty of Agriculture, Department of Agricultural Economics, 76000 Igdir, Turkey
}

\begin{tabular}{llll} 
A R T I C L E & I N F O & \\
& & & \\
\hline Article history: & & & \\
Received & 19 & December & 2019 \\
Accepted & 24 & August & 2020 \\
Available online & 31 & August & 2020
\end{tabular}

Keywords:

Temperature change

Food price index

Gross production index

Cointegration

Causality

R E S E A R C H A R T I C L E

\begin{abstract}
A B S T R A C T
The effects of temperature change on different sectors have been one of the most essential problems in the last decades. Agricultural sector is definitely the most fragile sector of all, not only production of food causes temperature change but also temperature change led to the instability of production and prices. The objective of this study was to analyse the relationship between temperature change and production or price indices in the world for the period of 1990-2016. The time series of temperature change, Food Price Index and Gross Production Index for foods were obtained from the database of the Food and Agriculture Organization of the United Nations. Johansen cointegration and Granger causality analysis were used to evaluate relations between the indicators in the short and long runs. The results of the study indicated that temperature change, Food Price Index and Gross Production Index for foods were cointegrated and so they move together in the long run. On the other hand, Granger causality analysis highlighted that there is unidirectional causality runs from temperature change to both Food Price Index and Gross Production Index for foods and at the same time from Gross Production Index for foods to Food Price Index. This research concluded that temperature has an essential effect both on agricultural production and prices, whereas food prices are sensitive to production. Therefore, the environmentally friendly technologies should be developed and applied in agricultural sector. However, the food prices could be regulated via production controls which take temperature change into consideration.
\end{abstract}

@@ 2020 Turkish Journal of Forecasting by Giresun University, Forecast Research Laboratory is licensed under a Creative Commons Attribution-ShareAlike 4.0 International License.

\section{Introduction}

The latest global temperature change data of National Aeronautics and Space Administration (NASA) indicated that 2018 was the fourth warmest year. FAO confirmed this information such as the average global temperature change over land in 2018 was $1.19^{\circ} \mathrm{C}$ and the fourth warmest record of air temperature associated with climate change threaten plant growth and yield, putting millions of farmers and communities at risk throughout the world. Together with changes in precipitation and increases in extreme events such as flooding and droughts, temperature

\footnotetext{
* Corresponding author.

E-mail addresses: nevraalhas@tuik.gov.tr (Nevra Alhas Eroglu), mehmetbo@omu.edu.tr (Mehmet Bozoglu), ugur.baser@omu.edu.tr (Ugur Baser), bakiye.topuz@igdir.edu.tr (Bakiye Kilic Topuz)
} 
change threatens countries' food security and their ability to eradicate poverty and achieve sustainable development [1]. Therefore, the agenda of this century has considerably focused on the climate change and its effects on different sectors. Temperature change is one of the most susceptible indicators of climate change and agricultural sector is one of the most fragile sectors against temperature and climate changes. For this reason, the studies on the effects of climate change on agricultural sector are very essential to analyse the sustainability of agricultural sector.

The economic effects of climate change on agricultural production in developing countries has been reviewed by numerous studies [2-12] and it was introduced that climate change has considerable effect on agricultural crops in developing countries. In order to analyse the relation between climate change and yield, regression models [13-15] and time series techniques [16-18] have been used. The literature was substantially focused on crop production, but the agricultural sector required to be analysed in whole. Therefore, the objective of this study was to examine the relationship between the food indices, FPI and GPI with temperature change in the world for the period of 19902016.

The remainder of the paper was structured as follows. In the second section, the data and methodology of the research were introduced. In the third section, the model results and were presented and discussed. In the fourth section, conclusion and recommendations were introduced.

\section{Material and Methods}

\subsection{Material}

In this study, the time series of Food Price Index (FPI) Gross Production Index (GPI) for agriculture and temperature change were examined for the period of 1990-2016 and the data was obtained from the Food and Agricultural Organization [19-21].

The FPI is a measure of the monthly change in the international prices of a basket for food commodities. FPI was introduced in 1996 to monitor developments in the global agricultural commodity markets. FPI consists of 5 subcommodity group price indices such as cereals, dairy, meat, vegetable oils and sugar and their weights are 0.272 , $0.173,0.348,0.135$ and 0.072 , respectively [19]. In this study, annual deflated index series was used.

The GPI is an index of agricultural production and show the relative level of the aggregate volume of agricultural production for each year in comparison with the base period. The GPI index was based on the sum of price-weighted quantities of different agricultural commodities. The unit of GPI was valued in US Dollar [20].

Temperature change contains data on observed mean surface temperature changes by country over the period of 1961-2017. The data provide information on monthly, seasonal and annual average temperature anomalies. This study examined the temperature change for the period of 1990-2016 and the unit of temperature change is ${ }^{\circ} \mathrm{C}$ [21].

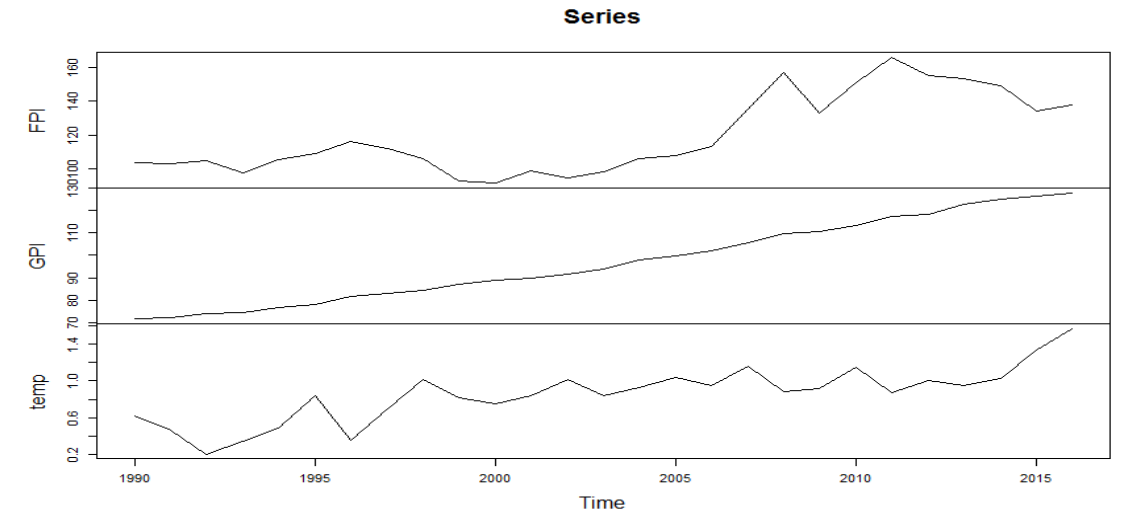

Figure 1. Time series graph of FPI, GPI and temperature change in the world for the period of 1990-2016

Figure 1 reported the time series of FPI, GPI and temperature change and highlighted that GPI has shown an increasing trend over the period of 1990-2016, whereas FPI and temperature change has shown fluctuations in time. 


\subsection{Method}

This study examined the short and long runs relationships between 2 food indices of FAO; FPI and GPI with temperature change. The long run relationship was examined by Johansen cointegration test and short run relationship was introduced by Granger causality test. The EViews 8 and RStudio were used in order to analyse the series via cointegration and causality methods.

The Johansen cointegration test can be seen as a multivariate generalization of Augmented Dickey-Fuller (ADF) test (Equation 1). The generalization is the examination of linear combinations of variables for unit roots. Johansen suggests a method for both determining how many cointegrating vectors there are and estimating all the distinct relationships [22]. The Johansen test and estimation strategy - maximum likelihood - make it possible to estimate all cointegrating vectors when there are more than two variables. If there are $\mathrm{n}$ variables which all have unit roots, there are at most $n-1$ cointegrating vectors [23].

$\Delta y_{t}=\left(a_{1}-1\right) y_{t-1}+\varepsilon_{t}$

In Granger causality test, there are more than two time series and the relationship among the series is analysed through the direction of them. The causality among two series such as $X_{t}$ and $Y_{t}$ can be revealed in Equation 2 and 3. The coefficients of the variables will be statistically significant if the causality runs from $X_{t}$ to $Y_{t}$ [24].

$$
\begin{aligned}
& Y_{t}=\sum_{i=1}^{m} \alpha_{i} Y_{t-i}+\sum_{j=1}^{m} \beta_{j} X_{t-j}+u_{1 t} \\
& X_{t}=\sum_{i=1}^{m} \lambda_{i} X_{t-i}+\sum_{j=1}^{m} \delta_{j} Y_{t-j}+u_{2 t}
\end{aligned}
$$

This study indicates that there is cointegration and causality among three indicators and therefore, there has been the short and long run relationships between FPI, GPI and temperature change.

\section{Results and Discussion}

Before application of any model, the unit root test should be taken into consideration. Autocorrelation (ACF) and partial autocorrelation (PACF) graphs of the series indicate that FPI, GPI and temperature change series are nonstationary at level (Figure 2). Therefore, Augmented Dickey-Fuller (ADF) was applied in order to decide whether the series have unit root or not.
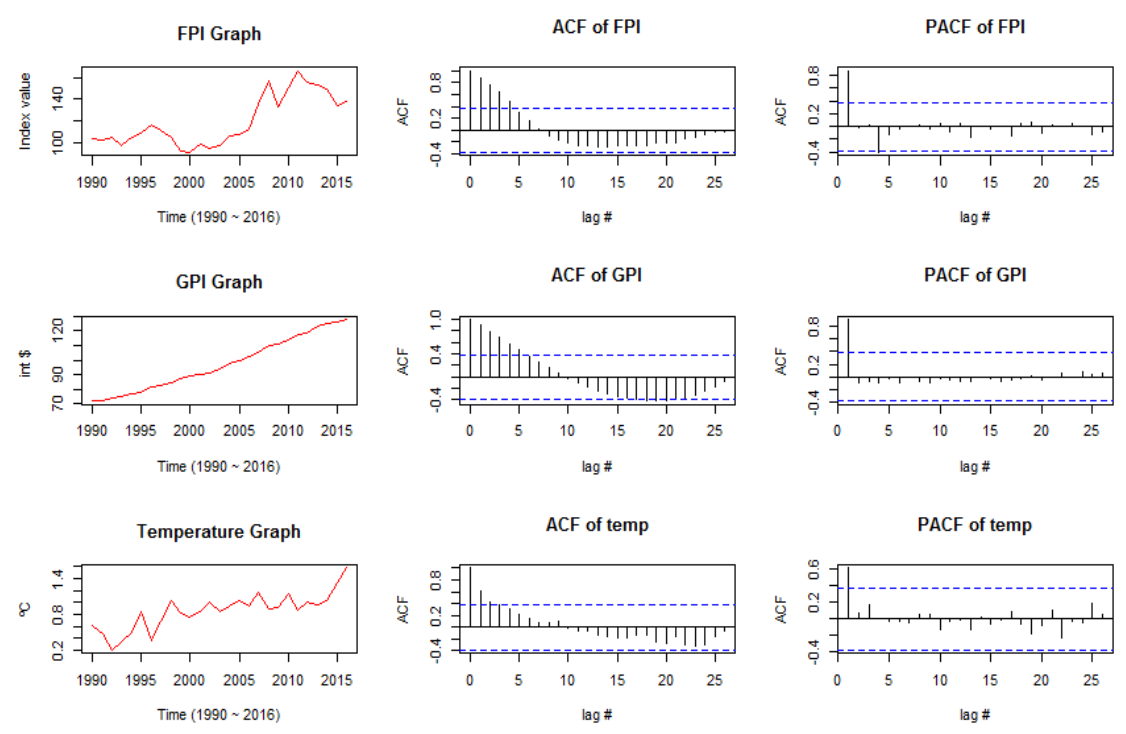

Figure 2. Time series graph and ACF-PACF plots of FPI, GPI and temperature changes in the world

ADF test results reported that we cannot reject the null hypothesis of unit root in the time series of FPI, GPI and temperature change and they are non-stationary (Table 1). However, all of the series are stationary in first-differences and the null of a unit root in the differenced of the series could be rejected. Therefore, the series are I (1). 
Table 1. The results of unit root test

\begin{tabular}{lcccc}
\hline \multirow{2}{*}{ Variables } & \multicolumn{2}{c}{ Level } & \multicolumn{2}{c}{ First-difference } \\
\cline { 2 - 5 } & $\boldsymbol{t}$-statistic & Prob. & $\boldsymbol{t}$-statistic & Prob. \\
\hline FPI & 0.378 & 0.786 & -5.079 & 0.000 \\
GPI & -2.754 & 0.225 & -5.808 & 0.000 \\
Temperature Change & 1.712 & 0.975 & -5.295 & 0.000 \\
\hline
\end{tabular}

As the series are stationary at first level, Johansen Cointegration Test could be applied in order to determine whether there is the long-run relation among the series. The results of the Johansen Cointegration Test with trace and Max-Eigen statistics indicated that FPI, GPI and temperature change are cointegrated (Table 2). Therefore, the null hypothesis of non-cointegration $(r=0)$ was rejected at the level of 0.05 significance and there is long-run relationship among the series.

Table 2. Johansen cointegration test results

\begin{tabular}{cccccccc}
\hline$H_{0}$ & Eigenvalue & Trace Statistics & 5\% Critical Value & Prob. & Max-Eigen Statistics & 5\% Critical Value & Prob. \\
\hline $\mathrm{r}=0$ & 0.708717 & 51.42855 & 42.91525 & 0.0057 & 27.13609 & 25.82321 & 0.0334 \\
$\mathrm{r} \leq 1$ & 0.554618 & 24.29246 & 25.87211 & 0.0776 & 17.79413 & 19.38704 & 0.0839 \\
$\mathrm{r} \leq 2$ & 0.255750 & 6.498332 & 12.51798 & 0.3998 & 6.498332 & 12.51798 & 0.3998 \\
\hline
\end{tabular}

All of the indicators were examined as dependent variable in VAR model and Granger Causality test results were reported in Table 3. The results highlighted that in FPI dependent variable model, GPI and temperature change were not Granger cause of FPI. Therefore, the null hypothesis was rejected for both of the causality relation. On the other hand, GPI dependent variable model revealed that no causality between FPI and GPI whereas causality runs from temperature change to GPI. So, null hypothesis was rejected for the former, whereas it was failed to reject for the latter. Lastly, temperature dependent variable model indicated that causality runs both from FPI and GPI to temperature change. For this reason, the null hypothesis could not be rejected. To sum up, there is bidirectional causality between GPI and temperature change and unidirectional causality from FPI to temperature change. The bidirectional causality between GPI and temperature change indicated that not only temperature change affects the agricultural production, but the quantity and quality of production also led to temperature change. [14] and [18] also introduced that temperature change with other climate variables had significant effects on yields whereas [13] revealed that climate had modest effects on yields. On the other hand, although no causality between production and price was revealed, causality from FPI to temperature change indicated that volatility in food prices was caused by excess demand and amount of production.

Table 3. Granger causality test results

\begin{tabular}{|c|c|c|c|}
\hline \multicolumn{4}{|c|}{ Dependent variable: FPI } \\
\hline Excluded & Chi-sq & df & Prob. \\
\hline GPI & 0.058766 & 1 & 0.8085 \\
\hline Temperature change & 0.679720 & 1 & 0.4097 \\
\hline All & 2.543821 & 2 & 0.2803 \\
\hline \multicolumn{4}{|c|}{ Dependent variable: GPI } \\
\hline Excluded & Chi-sq & df & Prob. \\
\hline FPI & 0.279026 & 1 & 0.5973 \\
\hline Temperature change & 5.078223 & 1 & 0.0242 \\
\hline All & 5.405022 & 2 & 0.0670 \\
\hline \multicolumn{4}{|c|}{ Dependent variable: Temperature change } \\
\hline Excluded & Chi-sq & df & Prob. \\
\hline FPI & 8.465829 & 1 & 0.0036 \\
\hline GPI & 20.81146 & 1 & 0.0000 \\
\hline All & 22.74389 & 2 & 0.0000 \\
\hline
\end{tabular}




\section{Conclusion}

This paper mainly focused on the relationship between temperature change and food indices of FAO via time series analysis. The results of the study indicated that the indices of FPI and GPI are cointegrated with the temperature change. The bidirectional causality between GPI and temperature change indicated that temperature change and GPI affect each other. In other words, agricultural production has simultaneously affected and affects the temperature change. For this reason, the agricultural sector should be regulated via policies which take sustainable and environmental development into consideration. By the way, the food production and environment could be considerably well managed. In brief, this study revealed that temperature change is the key indicator of agricultural sector and the price and production balance could not be maintained unless the external factors has been taken into consideration.

\section{References}

[1] FAO, 2019a. Food and Agriculture Organization, http://www.fao.org/economic/ess/environment/data/ temperature-hange/en/ (Accessed: 28.09.2019).

[2] F. P. Lansigan, W. L. de los Santos, J. O. Coladilla, "Agronomic impacts of climate variability on rice production in the Philippines", Agric. Ecosyst. Environ, vol.82, (2000), pp.129-137.

[3] C. C. Chang, "The potential impact of climate change on Taiwan's agriculture”, Agric. Econ, vol.27, (2002), 51-64.

[4] G. A. Gbetibouo and R. M. Hassan, "Measuring the economic impact of climate change on major South African crops: a Ricardian approach", Global Planet. Change, vol.47, (2005), 143-152.

[5] P. Kurukulasuriya and M. I. Ajwad, "Application of the Ricardian technique to estimate the impact of climate change on smallholder farming in Sri Lanka", Clim. Change, vol.81, (2007), 39-59.

[6] J. K. Kabubo-Mariara and F. K. Karanja, "The economic impact of climate change on Kenyan crop agriculture: a Ricardian approach", Global Planet. Change, vol.57, (2007), 319-330.

[7] D. Haim, M. Shechter, P. Berliner, "Assessing the impact of climate change on representative field crops in Israel agriculture: a case study of wheat and cotton", Clim. Change, vol.86, (2008), 425-440.

[8] A. Sanghi and R. Mendelsohn, "The impact of global warming on farmers in Brazil and India”, Global Environ. Change, vol.18, (2008), 655-665.

[9] T. T. Deressa and R. M. Hassan, "Economic impact of climate change on crop production in Ethiopia: evidence from cross-section measures", J. Afr. Econ, vol.18, (2009), 529-554.

[10] E. L. Moula, “An empirical assessment of the impact of climate change on smallholder agriculture in Cameroon”, Global Planet. Change, vol.67, (2009), 205-208.

[11] J. Wang, R. Mendelsohn, A. Dinar, J. Huang, S. Rozelle, L. Zhang, “The impact of climate change on China's agriculture”, Agric. Econ., vol.40, (2009), 323-337.

[12] M. Bozoğlu, U. Başer, N. Alhas Eroglu, B. Kılıç Topuz, "Impacts of Climate Change on Turkish Agriculture”, J. Int. Environmental Application \& Science, vol.14, no.3, (2019), 97-103.

[13] M. Isik and S. Devadoss, "An analysis of the impact of climate change on crop yields and yield variability”, Appl. Econ, vol.38, (2006), 835-844.

[14] D. B. Lobell and C. B. Field, "Global scale climate-crop yield relationships and the impacts of recent warming", Environ. Res. Lett, vol.2, (2007), 1-7.

[15] J. J. Almaraz, F. Mabood, X. Zhou, E. G. Gregorich, D. J. Smith, "Climate change, weather variability and corn yield at a higher latitude locale: South-western Quebec”, Clim. Change, vol.88, (2008), 187-197.

[16] B. Ozkan and H. Akcaoz, "Impacts of climate factors on yields for selected crops in Southern Turkey", Mitig. Adapt. Strat. Glob. Change, vol.7, (2002), 367-380.

[17] D. B. Lobell, K. N. Cahill, C. B. Field, "Historical effects of temperature and precipitation on California crop yields", Clim. Change, vol.81, (2007), 187-203.

[18] M. A. R. Sarker, K. Alam, J. Gow, "Exploring the relationship between climate change and rice yield in Bangladesh: An analysis of time series data", Agricultural Systems, vol.112, (2012), 11-16.

[19] FAO, 2019b. Food and Agriculture Organization, World Food Situation, FAO Food Price Index. http://www.fao.org/worldfoodsituation/foodpricesindex/en/ (Accessed: 28.09.2019).

[20] FAO, 2019c. Food and Agriculture Organization, Databases, Production, Production Indices. http://www.fao.org/faostat/en/\#data/QI (Accessed: 28.09.2019).

[21] FAO, 2019d. Food and Agriculture Organization, Databases, Agri-Environmental Indicators, Temperature change. 
http://www.fao.org/faostat/en/\#data/ET (Accessed: 28.09.2019).

[22] Johansen, 1998. Statistical Analysis of Cointegrating Vectors. Journal of Economic Dynamics and Control, Vol. 12, pp.231-254.

[23] G. Dwyer, 2015, “The Johansen Tests for Cointegration." Retrieved on the 24.02.2018 from http://www.jerrydwyer.com/pdf/Clemson/Cointegration.pdf.

[24] C. W. J. Granger, Investigating Casual Relations by Econometric Models an Cross Spectral Methods”, Econometrica, vol.37, (1969), 424-438. 